\title{
The Analysis of the Kiai's Charismatic Leadership and the Excellent Program in Marketing of Private Madrasah Aliyah in Jepara
}

\author{
Sukarman $^{1}$, Fatah Syukur ${ }^{2}$, Raharjo $^{3}$ \\ Universitas Islam Nahdlatul Ulama Jepara ${ }^{1}$ Universitas Islam Negeri Walisongo \\ Semarang 2,3 \\ \{pakar@unisnu.ac.id ${ }^{1}$, fsyukur68@gmail.com ${ }^{2}$, raharjo@walisongo.ac.id ${ }^{3}$ \}
}

\begin{abstract}
This paper analyzes the dynamics in marketing madrassas. This research is motivated by the phenomenon of ups and downs in the existence of madrasas. The focus and purpose of this study is to analyze the implications of the kiai's charismatic leadership style and superior programs in the marketing success of private Madrasah Aliyah which is marked by the high interest of the registrants. This field research is descriptive qualitative with a case study approach at private Madrasah Aliyah in Jepara. The results of this study are 1) Applicants 'interest is an implication of the kiai's charismatic leadership style 2) Applicants' interest is an implication of the excellent program 3) Applicant interest is an implication of both. The conclusion of this study is the kiai's charismatic leadership style and superior programs have implications for the successful marketing of private Islamic madrasah in Jepara simultaneously and partially.
\end{abstract}

Keywords: Leadership; Excelent Program; Madrasah; Marketing

\section{Introduction}

The marketing success of an organization can be measured by the high public interest. Although marketing is only considered as one of the many functions in a company, some marketers claim that marketing is the main function. The marketers quote Drucker that the goal of business is to create customers. They say that the job of marketing is to determine the company's mission, products and market. Another task of marketing is directing other functions in the task of serving custome [1]. Moreover, from the customers' point of view, recently, Peter Drucker has defined marketing 'as the whole business seen from the point of view of its final result, while Philip Kotler defines it as 'human activity directed at satisfying needs and wants through exchange processes' .[2]

Likewise with the marketing of educational services, marketing of educational services can be measured by the high interest of registrants. In other words, the applicant's interest is an indicator of the success of marketing educational services. Several educational institutions have succeeded in marketing their educational services. One of them is MTs Al-Islam Joresan. This is due to the great attention of educational institutions to the importance of marketing. [3] on the other hand, madrasah that consider marketing not important or that madrasah are not 
able to do marketing well are proven unable to attract public interest, meaning that madrasas cannot compete with schools or madrasas with their competitors.[4]

Kotler states the marketing success involves the components of the marketing mix (product, price, place, promotion).[5] The most important thing is the product. Without a product, marketing will not happen. Other elements of the marketing will exist if the product does. Although the product theory is a major factor in marketing success, this is different in the marketing of private madrasah education services in Jepara. Apart from the flagship program as an attraction, The figures/kyai are also a factor attracting interest in marketing madrasas. Subsequently, the questions are how far these two things have implications in the marketing of educational services; do leading figures/kyai and programs have implications for the marketing of Islamic education services in Jepara; which one is more dominant has implications for madrasah marketing.

\section{Methods}

This research is descriptive or survey one. The term survey is used for an investigative technique with direct observation of a phenomenon or the systematic collection of data from a population by means of personal contacts and interviews when adequate information about a particular issue is not available in records, files and other sources. The surveys are an important tool for gathering evidence related to specific social problems..[6] In this study, the survey was used to collect data on the marketing of educational services which focused on the main aspects that influenced the interest of private Islamic madrasah registrants in Jepara.

This is a field research with a case study approach. The case study method is a very popular form of qualitative analysis and involves careful and complete observation of a social unit, a person's unit, a family, an institution, a cultural group or even an entire community. It is a method of study in depth rather than breadth. The case studies place greater emphasis on a full analysis of a number of events or conditions and their relationships. The case studies discuss the processes that occur and how they are related. So, a case study is basically an intensive investigation of a particular unit under consideration. The object of the case study method is to find the factors that explain the behavior pattern of a given unit as an integrated totality.[7] The case study in this research was conducted at private Madrasah Aliyah Madrasah in Jepara.

The population and sample of this study were all private madrasah aliyah in Jepara. The researchers take the entire population into the sample because in qualitative (naturalistic) research it is different from conventional research (quantitative). The determination of the sample in qualitative research is not based on statistical calculations.[8] Many quantitative research uses probability sampling because it is considered very efficient. Sampling in qualitative research is different because it has different objectives than quantitative research.[9]

\section{Result and Discussion}

New product development is needed to increase marketing effectiveness. Kopf stated that the development of new products can improve market and customer orientation.[10] These products are excellent programs offered by madrasas in the form of intra-curricular programs, extra-curricular activities programs, and other excellent programs that differentiate one 
madrasah from another. However, in several cases in the field, data shows that several private Islamic madrasahs in Jepara have been successful in marketing educational services due to two main factors for superior programs and leadership from leaders / kiai.

The Implications of the Charismatic Leadership of the Kyai and the Flagship Program of the Private Madrasah Aliyah Marketing in Jepara

The dynamics of marketing educational services in Jepara come in competitive level. This is due to the high number of private madrassa. The statistical data on the number of madrasas in Jepara shows that the number of madrasas in Jepara is very large. Of many madrasas in Jepara, only less than $1 \%$ are public madrasah and the rest around $99 \%$ are private madrasah.

Table 1. Data on the number of private Madrasahs in Jepara. [11]

\begin{tabular}{lcccc}
\hline \multicolumn{1}{c}{ Level } & $\begin{array}{c}\text { Total of state } \\
\text { madrasah }\end{array}$ & $\begin{array}{c}\text { Total of } \\
\text { students }\end{array}$ & $\begin{array}{c}\text { Total of private } \\
\text { madrasah }\end{array}$ & $\begin{array}{c}\text { Total of } \\
\text { students }\end{array}$ \\
\hline $\begin{array}{l}\text { Madrasah Ibtidaiyah (Primary } \\
\begin{array}{l}\text { School) } \\
\text { Madrasah Tsanawiyah (First }\end{array}\end{array}$ & 2 & 1.345 & 190 & 34.323 \\
$\begin{array}{l}\text { High School) } \\
\begin{array}{l}\text { Madrasah Aliyah (Secondary } \\
\text { High School) }\end{array}\end{array}$ & 2 & 1.882 & 111 & 24.373 \\
\hline
\end{tabular}

At Jepara there are 62 Madrasah Aliyah consisting of 60 Private Aliyah Madrasas (MAS) and only 2 State Madrasah Aliyah (MAN). The distribution is as follows;

Table 2. Data on the number of private Madrasah Aliyah, students and teachers in Jepara.[12]

\begin{tabular}{|c|c|c|c|c|c|c|c|c|c|}
\hline \multirow{3}{*}{$\begin{array}{c}\text { Sub- } \\
\text { district } \\
\text { s }\end{array}$} & \multirow{2}{*}{\multicolumn{2}{|c|}{ Number of }} & \multicolumn{6}{|c|}{ Private Madrasah Aliyah (MA) } & \multirow{3}{*}{$\begin{array}{c}\text { Ratio } \\
\text { Student- } \\
\text { Teacher }\end{array}$} \\
\hline & & & \multicolumn{3}{|c|}{ Students } & \multicolumn{3}{|c|}{ Teachers } & \\
\hline & & & $\mathbf{L}$ & $\mathbf{P}$ & Total & $\mathbf{L}$ & $\mathbf{P}$ & Total & \\
\hline 1 & Kedung & 11 & 1,029 & 1,463 & 2,492 & 102 & 33 & 135 & 18.46 \\
\hline 2 & Pecangaan & 3 & 396 & 564 & 960 & 29 & 21 & 50 & 19.20 \\
\hline 3 & $\begin{array}{l}\text { Kalinyamat } \\
\text { an }\end{array}$ & 4 & 315 & 472 & 787 & 32 & 20 & 52 & 15.13 \\
\hline 4 & Welahan & 2 & 123 & 131 & 254 & 17 & 8 & 25 & 10.16 \\
\hline 5 & Mayong & 3 & 242 & 413 & 655 & 33 & 14 & 47 & 13.94 \\
\hline 6 & Nalumsari & 4 & 266 & 495 & 761 & 25 & 13 & 38 & 20.03 \\
\hline 7 & Batealit & 3 & 146 & 186 & 332 & 21 & 14 & 35 & 9.49 \\
\hline 8 & Tahunan & 5 & 443 & 528 & 971 & 42 & 25 & 67 & 14.49 \\
\hline 9 & Jepara & 2 & 97 & 91 & 188 & 24 & 6 & 30 & 6.27 \\
\hline 10 & Mlonggo & 4 & 401 & 602 & 1,003 & 40 & 22 & 62 & 16.18 \\
\hline 11 & Pakis Aji & 3 & 127 & 217 & 344 & 21 & 16 & 37 & 9.30 \\
\hline 12 & Bangsri & 7 & 1,146 & 1,245 & 2,391 & 65 & 38 & 103 & 23.21 \\
\hline 13 & Kembang & 3 & 142 & 216 & 358 & 16 & 9 & 25 & 14.32 \\
\hline 14 & Keling & 0 & 0 & 0 & 0 & 0 & 0 & 0 & 0.00 \\
\hline 15 & Donorojo & 7 & 364 & 493 & 857 & 50 & 23 & 73 & 11.74 \\
\hline 16 & $\begin{array}{l}\text { Karimun } \\
\text { Jawa }\end{array}$ & 1 & 39 & 45 & 84 & 8 & 6 & 14 & 6.00 \\
\hline Jumlah & & 62 & 5,276 & 7,161 & 12,437 & 525 & 268 & 793 & 15.68 \\
\hline
\end{tabular}

Source: Ministry of Religion Office of Jepara Regency 
Based on the data on the number of private Madrasah Aliyah in Jepara, the distribution data is obtained. The highest number of private Aliyah madrasas is in Kedung sub-district. The second instrument is Bangri Sub-district. The third rank is Donorojo subdistrict, the next order is Tahunan sub-district, Mlonggo, Nalumsari, and Kalinyamatan subdistrict, to the end of data.

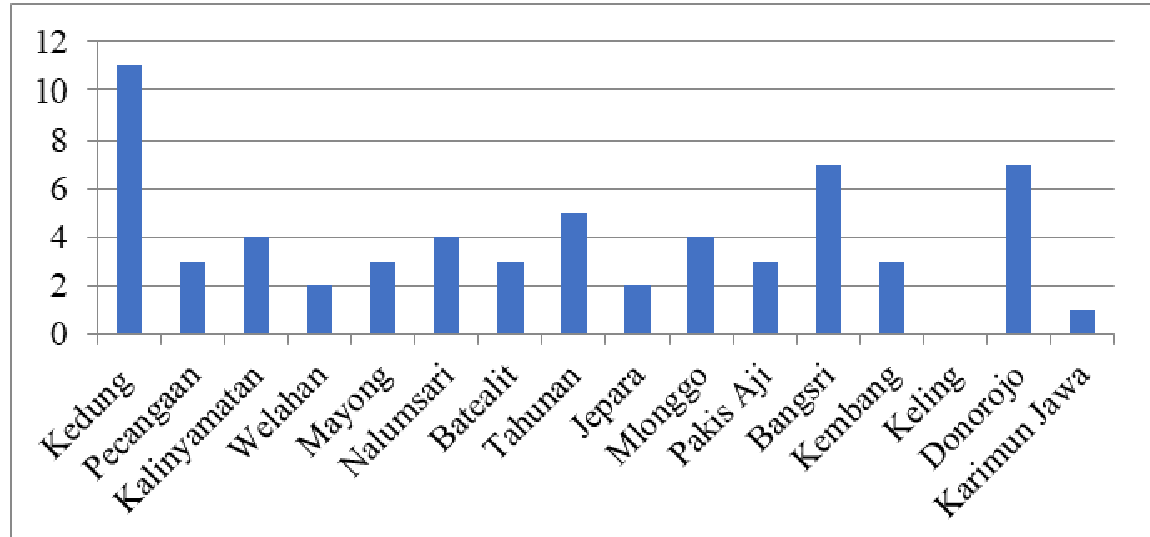

Fig 1. Data on the distribution of private Madrasah Aliyah in each sub-district in Jepara Regency

Each Madrasah Aliyah has its own charm. In general, the marketing of private madrassa at Jepara can be seen from the aspect of the main attraction on how much it has implications for the applicant's interest, namely the kiai charisma, superior programs, and a combination of both. Based on a survey on Madrasah aliyah alumni in Jepara, the following data were obtained:

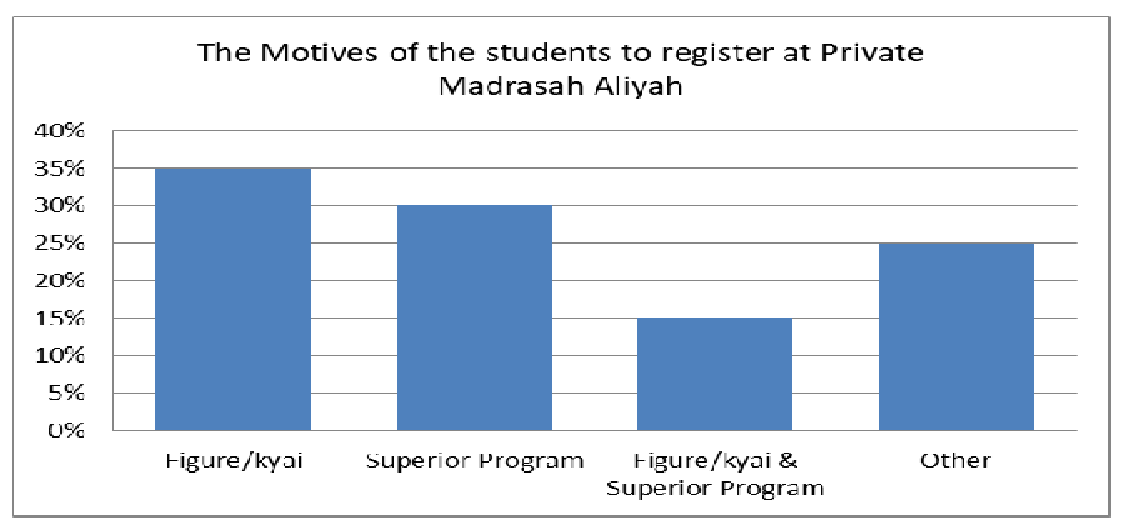

Fig 2. The survey table on the motives of students registering at private Madrasah Aliyah in Jepara

Based on the survey data, data shows that the kiai/leadership figures occupy the highest position as a factor influencing the applicant's interest in private Islamic madrasah in Jepara. While the superior program took second place. The third position is a combination of kiai figures / figures and featured programs. Meanwhile, the rest is influenced by other factors. Some examples of cases for example; 


\section{a) MA Hasyim Asy'ari Bangsri Jepara}

This private madrasah is one of the Madrasah Aliyah which has been successful in marketing educational services. This can be seen from the high interest of registrants. The active student data is 1221 students.[13] This high public interest is influenced by two dominant factors, namely the charismatic figure of the founder and the flagship program of Immersion. The Immersion Program is the learning of one or several subjects using a foreign language as the language of instruction. The Immersion program at MA Hasyim asy'ari has a significant positive impact on students, namely: 1) the students have high self-confidence and are good mentally. 2) students have a varied vocabulary. 3) student achievement increases. 4) students have a higher chance of being accepted into tertiary institutions. [14] the figure of the kiai KH. Amin Sholeh as the founding figure of the Hashim Asy'ari foundation has also become a magnet for registrants at the institution.

\section{b) MA Matholiul Huda}

It is not much different from MA Hasyim Asy'ari, MA Matholi'ul Huda is a Madrasah that is successful in marketing educational services. The indication is the number of students who remain high. Even though it doesn't have a specific flagship program. However, MA Matholiul Huda has a salaf style as the uniqueness and uniqueness of the madrassa. On the other hand, the figure of $\mathrm{KH}$. Mawardi, as the founder, has become a magnet for public interest.[15]

\section{c) MA Matholibul Huda}

Madrasah aliyah Mathalibul Huda has an excellent academic program Mathalibul Huda Mathematical Olympiad (MMO), namely nursery and science olympiad mentoring. This academic excellence program is a trade mark attached to Madrasah aliyah Mathalibul Huda.[16]

\section{Conclusion}

Theoretically, marketing is selling products (goods or services) like the marketing of educational services. The educational service products are considered as the main tool to attract public interest. However, this is not the case with the marketing of private Madrasah Aliyah in Jepara. Although the products of madrassas are superior programs, they can influence public interest, but not the main factor. In fact, there are other factors that are more dominant than the flagship program, namely kiai/figures. On the other hand, the combination of both also has implications for the enthusiasm of registrants in private Aliyah madrasas in Jepara. In conclusion, the figures of kiai/leading figures and programs can have implications for the successful marketing of private madrasah aliyah in Jepara partially and simultaneously.

\section{References}

[1] P. Kotler, G. Armstrong, J. Saunders, and V. Wong, Principles of Marketing: European Edition, 2nd ed. New Jersey, USA: Financial Times/ Prentice Hall, 1999. 
[2] T. Hannagan, Tim Marketing for the Non-profit Sector, 4th ed. London: MACMILLAN PRESS LTD, 2010.

[3] N. Finawati, "NILAI PANCA JIWA DI MADRASAH TSANAWIYAH AL-ISLAM JORESAN MLARAK PONOROGO,” INSTITUT AGAMA ISLAM NEGERI ( IAIN ) PONOROGO PASCASARJANA, 2020.

[4] Dian, I. Rosbiah, and A. Prayoga, "Implementasi Strategi Pemasaran Pendidikan di Madrasah,” Dirasah J. Stud. Ilmu dan Manaj. Pendidik. Islam, vol. 3, no. 1, pp. 1-14, 2020.

[5] C. Lovelock and L. Wright, Principles of Service Marketing and Management, 1st ed. London: Oxford and Cambridge, 2019.

[6] P. Pandey and M. M. Pandey, RESEARCH METHODOLOGY: TOOLS AND TECHNIQUES. Romania, European Union: BRIDGE CENTER, 2015.

[7] C. R. Kothari, Research Methodology: Methods \& Techniques. New Delhi, India: New Age International (P) Limited, Publisher, 2004.

[8] Sugiyono, Metode Penelitian Kuantitatif, Kualitatif dan R\&D, 26th ed. Bandung: Alfabeta, 2017.

[9] W. L. Neuman, Social Research Methods: Qualitative and Quantitative Approaches. England: Pearson Education Limited, 2014.

[10] L. Huempfner and D. A. Kopf, "Using stakeholder marketing and social responsibility for new product development in higher education : a business Spanish model," J. Mark. High. Educ., vol. 0, no. 0, pp. 1-23, 2017.

[11] Religion Ministry of Jepara Regency, "Open Data Kabupaten Jepara," http://opendata.jepara.go.id/id/group/pendidikan, 2018. .

[12] Badan Pusat Statistik Kabupaten Jepara (Statistics Jepara), "Percentage Population According To The Religion Which They Follow in Jepara Regency," Badan Pusat $\begin{array}{lll}\text { Statistik, } 2020 . & \text { [Online]. Available: }\end{array}$ https://jeparakab.bps.go.id/statictable/2017/02/16/433/tabel-table-4-3-1-prosentasependuduk-menurut-agama-yang-dianut-di-kabupaten-jepara-2015.html.

[13] SIAP, "MA Hasyim Asy'ari Bangsri," Sistem Informasi Aplikasi Pendidikan (SIAP) Web Sekolah weblog, 2020. [Online]. Available: http://20318719.siapsekolah.com/data-siap/siswa-daftartingkat/. [Accessed: 30-Sep-2020].

[14] S. Andriyani, "The Implementation of Immersion Program of Second Grade at MA Hasyim Asy’ari Bangsri Jepara Jawa Tengah,” J. Chem. Inf. Model., vol. 53, no. 9, pp. 1689-1699, 2019.

[15] "Interview with H Sarwadi, principle of MA Matholiul Huda Jepara, 28 December $2020, " 2020$.

[16] P. JAMBU, "Profil MA Matholibul Huda," Media Informasi \& data base Pemdes Jambu Kecamatan Mlonggo Kabupaten Jepara Jawa Tengah, 2020. [Online]. Available: huda.html. http://www.desajambu.com/2015/05/madrasah-aliyah-matholibul- 